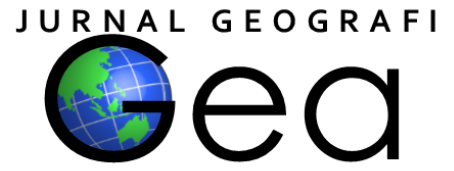

\title{
THE EFFECT OF INTERACTIVE BLENDED-PROBLEM BASED LEARNING ASSISTED VIRTUAL CLASSROOM ON CRITICAL THINKING SKILLS OF STUDENTS OF THE SOCIETY ERA 5.0
}

\author{
Muhammad Naufal Islam ${ }^{1 *}$, Sumarmi ${ }^{2}$, Alfyananda Kurnia Putra ${ }^{3}$, Pratiwi Sugiyati ${ }^{4}$ and \\ Sabrina Salsabilah ${ }^{5}$ \\ 1,2,3,4,5 Department of Geography, Faculty of Social Science, Universitas Negeri Malang \\ *mnaufalislam.1707216@students.um.ac.id
}

\begin{abstract}
Students in 5.0 society education are directed to have adaptive and reactive response patterns to change through effective synergy as domain systems inaccessibility to technology in developing their skills actively and independently through critical thinking skills. Critical thinking skills as a cognitive domain in identifying, analyzing, and practical thinking and creative ways to solve problems are needed to survive in the era of global society 5.0. Therefore, teachers are required to design learning processes that can accommodate student competencies in the era of society 5.0, one of which is the implementation of the innovative Interactive Blended Problem-Based Learning (IBPBL) learning model. This study aims to determine the effect of Interactive Blended ProblemBased Learning (IBPBL) assisted by Virtual Classroom on students' critical thinking skills. This type of research is a quasi-experimental study using a posttest-only control group design. The sample in this study used 72 students in class XIPS 2 ( $n=36$ control class) and XIPS 3 ( $n=36$ experimental class), Specializing in Social Sciences, SMAN 1 Tempeh, Lumajang Regency, East Java. The data analysis technique used the independent $t$-test hypothesis test to determine the significance value of the difference in the average treatment given to both the control and experimental classes. The results showed an effect of Interactive Blended Problem-Based Learning (IBPBL) assisted by Virtual Classroom on the critical thinking skills of students with Sig. (2-tailed) 0.000.

Keywords: Interactive Blended Problem-Based Learning, Virtual Classroom, Critical thinking skills
\end{abstract}

\section{INTRODUCTION}

The era of society 5.0 became the concept of a new order of life, integration of human-centered technology. Humans are not only objects but also subjects of controlling science (Wang et al., 2020) and technologybased integrated society life (Baszuk \& Heath, 2020; Fu et al., 2020). The concept of society 5.0 as a solution to the turmoil of digital technology disruption impacts all aspects of life (Legido-Quigley et al., 2020; Shiroishi et al., 2018), including the education aspect.

In education, society 5.0 brought fundamental changes to the achievement of student competencies. Students are required to achieve the goals of the existing learning objectives (Duma \& Monda, 2013), have competence in digital literacy, and be humancentered in the application of complex technological systems (Gladden, 2019). Based on macro-learning, students must have adaptive and reactive response patterns to change through effective synergy as domain systems are inaccessible to technology (Suzuki et al., 2021). Then in micro-learning, students are required to develop their skills actively and independently both in the affective, psychomotor, and cognitive aspects (Sajidan et 
al., 2020), one of which is critical thinking skills.

Critical thinking skills as a cognitive skill in identifying, analyzing, practical thinking and creative ways to solve problems are needed to develop in the era of a global society. Students need critical thinking skills in dealing with a super-smart society (Jahanian \& Rajabi, 2016), which have an impact on developing the realm of competence and skills, including creativity (Rosa \& Mujiarto, 2020), innovation (Short \& Keller-Bell, 2020), problem-solving (Pereira, A. G., Lima, T. M., \& Charrua-Santos, 2020), collaboration (Sugiyanto et al., 2021), and communication (Guo et al., 2020). Therefore, teachers as facilitators in the learning process are required to present a learning process that leads to the achievement of high-level cognitive (critical thinking skills), one of which is the application of appropriate instructional design through the Interactive Blended Problem-based Learning (IBPBL) model.

IBPBL, as an integration of instructional design, is an effective solution in achieving students' critical thinking skills. IBPBL has the opportunity to develop critical thinking skills through discovery learning activities, asking questions, articulations, descriptions, remembering, and responsible decision making (Effendi \& Hendriyani, 2020). The integration of the two models has a positive influence on learning. Blended-based learning as a learning model emphasizing the applicative integration of technology accessibility helps students connect with the material contained in a complex and deep manner (Aquino \& BuShell, 2020). Then, the Problem-based learning model gives students cognitive guidance so that they can solve problems comprehensively (Ural \& Dadli, 2020). The emphasis of IBPBL lies in learning activities in the form of interactivity with effective feedback between teachers, students, learning materials, and technology. Improved practical domains and problem-solving abilities can be increased through the Blended Problem-based Learning model (Tsai \& Tang, 2017) and integrated interactive technology (IBPBL). Then, implementing IBPBL can affect achievement by increasing students' awareness of metacognition (Yuan et al., 2020) through acceleration-integration of digital technology in learning activities (Altık et al., 2019). Therefore, instructional design becomes an essential domain in learning, and geography is no exception.

As the mother of science in the study of social sciences, Geography has unique characteristics in its position as a subject in learning. Geography as an integrative discipline (Oktavianto et al., 2017) which is location-oriented (Larsen \& Harrington, 2018), based on a natural approach (Dolan et al., 2014), and prioritizes the environment as a learning resource (Prasetya, 2018) provides many contributions to optimizing the achievement of education and learning in the era of society 5.0 .

The position of geography in education and learning in society 5.0 has a positive impact on the development of students' complex competencies and skills. The digital revolution provides a new ecosystem in knowledge in the form of geography (Geoknowledge) (Ratti, 2018). Then, furthermore, the Geography knowledge ecosystem has a unique domain in the reconstruction and actualization of the competency system in students (Mehren et al., 2018). Such a framework is necessary considering that the digital revolution is closely related to transcending distance, location, and geographical boundaries. Students with specialization in social sciences, including geography learning, have an excellent opportunity to obtain massive and complex information in improving critical thinking skills through implementing the global awareness curriculum (Tsang et al., 2020) so that they can reconstruct global based-competency (Harshman, 2016) in answering and solving global problems and issues, especially in the study of Geography. However, the implementation of such a learning process has various obstacles in the field.

The learning challenges of technological disruption have significant consequences for the science of Geography. The fulfillment and achievement of these learning experiences various obstacles, mainly 
related to the broad characteristics of the material in Geography learning, are at significant risk in the acceptance and acquisition of biased material (Lee et al., 2021). Then, today, all learning subjects in Indonesia are affected by the COVID-19 pandemic, which can cause academic loss (Nugraha, M. S., Liow, R., \& Evly, 2021), as a result of the reduced role of teachers in learning and the limitations of students in accessing relevant learning resources. Geography learning activities previously constructed with rote concepts impacted students' low critical thinking skills (Saptorini et al., 2021), both in academic demands and decision-making in overcoming students' independent learning problems. Therefore, it is necessary to have an instructional design, one of which is an innovative learning model in improving the quality of learning.

This research has an element of novelty, where researchers have not found similar research either to be applied to the subject of learning broadly or in the field of learning Geography. This research is a continuation of research conducted by (Effendi \& Hendriyani, 2020), wherein in his research, he carried out conceptual and hypothetical modeling regarding Interactive Blended Problem-Based Learning (IBPBL). Based on the results of his research, IBPBL has enormous potential to be implemented in the learning process, including Geography. Considering that IBPBL can provide a fun and conducive learning atmosphere, flexibility, accessibility, and is oriented towards achieving high-level cognitive skills in students. Such learning models are very relevant to be applied now, especially massive technological disruption and the demands of ideal learning during the COVID-19 pandemic. Therefore, this research has several objectives and benefits in the continuity of learning Geography optimally.

This study aims to determine the effect of Interactive Blended Problem-Based Learning (IBPBL) assisted by Virtual Classroom on students' critical thinking skills. Based on the research objectives, it was found that the benefits of research were (1) for teachers, providing an overview, insight, and new knowledge related to instructional design innovations and effective learning models that are relevant to the needs of integrated geography learning with technology; (2) For students, improving academic quality through improving skills in higher-order thinking; and (3) For schools, it becomes the basis for making policies on the technical implementation of effective educational and learning processes in instructional design innovations and learning models that are integrated with technology.

\section{RESEARCH METHOD}

This research belongs to the type of quasi-experimental research. This study aimed to determine the effect on research variables under controlled conditions (Sugiyono, 2016). Then, this study uses the Posttest Only Control Group Design research design, intending to avoid treatment that can affect the credibility of the posttest results in the research process (Jaedun, 2011). The research design is shown in table 1 as follows:

Table 1. Research Design

\begin{tabular}{lcc}
\hline \multicolumn{1}{c}{ Groups } & Treatment & Test \\
\hline Experiment & $\mathrm{X}$ & $\mathrm{O}_{1}$ \\
Control & - & $\mathrm{O}_{2}$ \\
\hline & & Source: Sugiyono (2016)
\end{tabular}


Notes:

$X \quad$ : Interactive Blended Problem based Learning (IBPBL) model treatment

- $\quad$ : No treatment (conventional learning model)

O1 : Posttest critical thinking skills experimental group

O2 : Posttest critical thinking skill control group

\section{Research Hypothesis}

The hypotheses in this study (1) H0, there is no significant effect of IBPBL assisted by virtual classroom on critical thinking skills; (2) $\mathrm{Ha}$, there is a significant effect of IBPBL assisted by virtual classroom on critical thinking skills.

\section{Research Subject}

The location of this research is SMAN 1 Tempeh, Lumajang Regency, East Java Province. The population in this study used class X (ten) students in the Social Sciences specialization with the academic year 2020/2021. The research sample selection used a simple random sampling technique so that the research sample of X IPS 2 (control class) was 36 students and X IPS 3 (experimental class) was 36 students. The scope of the material in this study is contained in KD. 3.6 Analyzing Atmospheric Dynamics and Its Impact on Life with a focus on the sub-material of The Effect of Global Climate Change on Life, in semester 12013 Curriculum (Revised Edition).

\section{Research Procedure}

This research was conducted in three (3) meetings at SMAN 1 Tempeh, either synchronously or asynchronously. Then, in carrying out the research using the Interactive Blended Problem Based Learning (IBPBL) model referring to (Effendi \& Hendriyani, 2020) with five learning syntaxes including (1) Introduction; (2) Starting a New Problem; (3) Follow Up Problems; (4) Performance Presentation; and (5) After Conclusion Problem.

\section{Assessment Technique Test and Statistical Test}

The assessment in this study was packaged in the form of an essay with five questions. Items refer to the critical thinking skills variable indicator (Ennis, 1996), which consists of (1) formulating the problem; (2) Disclosing the facts; (3) Able to argue (logical, accurate, and relevant); (4) Able to present ideas from different perspectives; (5) Able to provide an overview of the decisions taken. Then, the statistical tests in this study were instrument tests, prerequisite tests, and hypothesis testing assisted by IBM SPSS Statistics 20.

In the instrument test to determine the validity and reliability of the instrument, the researcher tested 30 respondents (students) at SMAN 1 Tempeh. Based on the research instrument test, the research instrument was declared valid $(<0.05)$ and reliable $(>0.60)$. Then, based on the prerequisite test, the research data was declared normal (Kolmogorov-Smirnov method) in the control group (.200) and the experimental group (.176) by exceeding the probability level $(>0.05)$ and homogeneous (Levene method) with the test results exceeding probability level $(>0.05)$ with a value of .206 . Then related to hypothesis testing, the researcher used a t-test with an independent t-test. The decision-making criteria for hypothesis testing are based on the value of sig. (2-tailed) $<0.05$ (Ha accepted) and sig. (2-tailed) $>0.05$ (Ha rejected).

\section{RESULTS AND DISCUSSION}

This research was conducted with $\mathrm{X}$ IPS 2 (control groups) and $X$ IPS 3 (experimental groups). The control groups were given no treatment using the conventional learning model, and the experimental group was given treatment using the IBPBL model in the sub material of Effects of Global Climate Change on Life. Based on descriptive statistical data analysis, student achievement on critical thinking indicators has a significant difference (Table 2 ). 
Table 2. Critical Thinking Indicator Frequency Distribution

\begin{tabular}{ccc}
\hline \multirow{2}{*}{ Value (\%) } & \multicolumn{2}{c}{ Frequency } \\
\cline { 2 - 3 } & Control & Experiment \\
\hline $86-100$ & 7 & 14 \\
$71-85$ & 17 & 14 \\
$56-70$ & 12 & 8 \\
$41-55$ & 0 & 0 \\
$<40$ & 0 & 0 \\
\hline \multicolumn{2}{c}{ Source: Data analysis (2021) }
\end{tabular}

Table 2 shows the frequency of the influence of the IBPBL model on students' critical thinking skills in descriptive statistics. The frequency results show that the conventional learning model's control group has critical thinking skills in the medium range $(71-85 \%)$ at $\mathrm{n}=17$ students. This condition is inversely proportional to the experimental class with the distribution of the frequency of critical thinking skills indicators of the IBPBL effect on the top average $(71-85 \%$ and $86-$ $100 \%$ ) at $n=14$, respectively.
Then, based on hypothesis testing in answering research questions, with $\mathrm{H} 0$, there is no significant effect of IBPBL's influence on critical thinking skills assisted by virtual classroom on critical thinking skills, and $\mathrm{Ha}$, there is a significant influence of IBPBL's influence on critical thinking skills assisted by virtual classroom on critical thinking skills. The test results are shown in Table 3.

Table 3. Research Mean and Standard Deviation

\begin{tabular}{ccc}
\hline Value (\%) & Mean & Sig. \\
\hline Experiment & 76 & 0.000 \\
Control & 81 & 0.000 \\
\hline \multicolumn{3}{c}{ Source: Data analysis (2021) }
\end{tabular}

Table 3 shows that descriptively statistically, there is an effect of IBPBL assisted by virtual classrooms on students' critical thinking skills, both in the experimental (0.000) and control (0.000) groups. The basis for decision making on hypothesis testing descriptively shows that the study results have a significant effect, with $\mathrm{H} 0$ being rejected and $\mathrm{Ha}$ is accepted. In addition, the results of significance can be seen in hypothesis testing through the results of the $\mathrm{t}-$ test (independent t-test), which are shown in table 4 as follows.

Table 4. Research Independent T-Test Test

\begin{tabular}{ccccccc}
\hline & $\begin{array}{c}\text { Levene's } \\
\text { test }\end{array}$ & Sig. & \multicolumn{3}{c}{ t-test for Equality of Means } \\
Equal variances assumed & $\mathbf{F}$ & & $\mathbf{t}$ & $\mathbf{d f}$ & Sig. (2-tailed) \\
Equal variances not assumed & .119 & .731 & 7.844 & 70 & .000 \\
\hline & & & 7.844 & 69 & .000 \\
\hline
\end{tabular}


Table 4 shows that IBPBL assisted by virtual classrooms has a positive effect on students' critical thinking skills. The significance of the p-value $(0.000)<0.05$ became the basis for Ha's decision, and $\mathrm{H} 0$ was rejected. This condition shows that critical thinking skill indicators can be improved with the right instructional design in IBPBL assisted by a virtual classroom.

Statistically descriptive (table 3 ), there is a difference (gain score) in the treatment between the experimental and control groups. The mean value of the experimental group (81) is higher than the mean value of the control group (76) as an implication of implementing the virtual classroom-assisted IBPBL learning model. Then, to find out the relationship between IBPBL-assisted virtual classroom indicators, the indicators can be shown in table 5 as follows:

Table 5. The Influence of the IBPBL Model assisted by virtual classrooms with Students' Critical Thinking Skills Experimental and Control Class Indicators

\begin{tabular}{lccc}
\hline \multicolumn{1}{c}{$\begin{array}{c}\text { Critical Thinking Skills } \\
\text { Indicators }\end{array}$} & Score & \multicolumn{2}{c}{ Mean } \\
\cline { 3 - 4 } & & Experiment & Control \\
\hline Formulate the problem & 100 & 85 & 85 \\
Revealing facts & 100 & 85 & 90 \\
$\begin{array}{l}\text { Give arguments } \\
\begin{array}{l}\text { Give ideas from different } \\
\text { points of view }\end{array}\end{array}$ & 100 & 75 & 85 \\
$\begin{array}{l}\text { Able to provide an overview } \\
\text { of the decisions taken }\end{array}$ & 100 & 70 & 60 \\
Mean & 100 & 81 & 60 \\
\hline
\end{tabular}

The results of the effect of the IBPBL model on students' critical thinking skills have results that are not much different between the experimental group and the control group. Such conditions have become research findings, mainly related to the online learning environment during the COVID-19 pandemic in influencing student learning activities. The IBPBL learning model with Blended Learning (BL) instructional design is oriented towards independent and student-centered learning (Bahri et al., 2020; Wong, 2013) and Problembased Learning (PBL) with active learning activities (Oderinu et al., 2020) through asking questions, problem-solving and critical thinking (Nargundkar et al., 2014) have become student learning habits during the covid-19 pandemic. Therefore, critical thinking indicators in formulating problems, revealing facts, and providing arguments have no significant effect on both the experimental and control groups. Students' critical thinking skills develop rapidly during online learning (Carolina Torres Escobar, 2021). However, students' critical thinking skills can emerge continuously with the integration of technology in instructional design (Bloom \& Doss, 2020). Such treatment was obtained in the experimental group in the implementation of the IBPBL model.

The IBPBL model effectively affects the indicators of students' critical thinking, namely providing ideas through different perspectives and providing an overview of the decisions taken. The IBPBL model can improve students' critical thinking through learning activities of finding, asking, elaborating, problem-solving, and reflection (Effendi \& Hendriyani, 2020). Optimizing students' critical thinking skills can help problem-solving, systematic, and logical thinking (Zamroni et al., 2020). Such conditions also require the development of 
critical thinking aspects of students, especially in providing an overview of the decisions that have been taken as a form of formulation of a problem (Sujanem et al., 2020). Then, the selection of the right material in the form of a sub material of the Effect of Global Climate Change on Life as one of the discussions in Geography in science learning by raising the context of real problems can support the optimization of students' critical thinking skills
(Dinata et al., 2020). Geography prioritizes the learning process of critical thinking and solutions in the content of learning values so that it has an impact on the development of student's critical thinking skills (Rahmatia Rahmatia, Ahmad Yani, 2018). The relationship of the influence of the IBPBL model variable on students' critical thinking skills is shown in table 6 .

Table 6. The relationship between the IBPBL model assisted by virtual classrooms and students' critical thinking skills

\begin{tabular}{cll}
\hline No & \multicolumn{1}{c}{ IBPBL Syntax } & Critical Thinking Skills Indicators \\
\hline 1 & Introduction & Formulate problems and understand \\
- & Students are given motivation and \\
guidance to see, observe and read the & \\
material that has been uploaded in & \\
google classroom. & \\
- Students are asked questions about & \\
the material & \\
Starting a New Problem \\
The teacher invites students to find and \\
collect relevant information related to \\
the questions given by the educator. \\
Problem Follow Up \\
- Students present information that has different points of view \\
been obtained from various sources, \\
the teacher guides students to \\
elaborate the concept of the material \\
towards understanding the topic \\
being taught.
\end{tabular}

3 Performance Presentation

- Students present the results of the analysis individually (appointed)

\section{After Conclusion Problem}

- Students do question and answer, at the time of question and answer students may express criticism, suggestions and comments
Able to provide an overview of the decisions taken 
- Teachers and students make conclusions about the things that have been learned related to the material

- Students are then given the opportunity to ask again things that have not been understood

Source: Data analysis (2021)

Based on table 5 shows that there is a relationship between the IBPBL model assisted by virtual classrooms and students' critical thinking skills. In the syntax of introduction and starting new problems, it impacts increasing students' critical thinking skills through sub-indicators of formulating problems and understanding problems, as well as revealing facts. The complexity of the access to technology in virtual classrooms in learning activities can help students organize information comprehensively (Fitri Rahmawati et al., 2020). Learning activities by providing an overview and basic questions can comprehensively provide students with an indepth understanding (Musthofa \& Sujadi, 2020).

Then, the second syntax related to the follow-up problem affects giving arguments, giving ideas from different points of view. Access to technology for Geography students can improve student experience (Lee, 2020) and be reduced to a new perspective in problem-solving (Hintermann et al., 2020). Such conditions are very relevant to be applied, considering that the current learning style of students is closely related to digital technology (Putra et al., 2021) so that new knowledge is formed through the synthesis of meaningful experiences in learning.

The third syntax, related to the integration of synthesizing knowledge with performance presentation and after conclusion problems, affects critical thinking skills to be able to provide an overview of the decisions taken. Responsible decision-making is a domain that must be mastered by students in science subjects (Chang et al., 2020). Educational technology with a virtual environment can improve students' critical thinking skills through learning activities of problem regulation and appropriate decisionmaking (Dexter et al., 2021). Then, through the model and selection of the right learning environment, critical thinking skills can emerge through organizing cognitive structures and thinking frameworks with learning activities showing authentic, logicalrational, and reliable evidence (Sari et al., 2021).

The era of society 5.0 had a massive impact on various aspects of human life, including the study of geography. The integration of technology as a domain in the learning process is shown in the appropriate instructional design. The IBPBL model assisted by virtual classrooms affects the development of students' critical thinking skills. IBPBL learning syntax includes: (1) Introduction; (2) Starting a New Problem; (3) Follow Up Problems; (4) Performance Presentation; and (5) After Conclusion Problems affect the critical thinking skill indicators in formulating problems, understanding problems, revealing facts, providing arguments, providing ideas from different perspectives, and being able to provide an overview of the decisions taken. The research findings show that the indicators of critical thinking in formulating problems, understanding problems, and revealing facts have no significant effect. This is because the online learning environment has shaped students' character and learning process actively and independently. Then, significant results were obtained on indicators providing ideas from different perspectives and providing an overview of decisions taken as a form of technology integration and selection of the suitable material. So that students can actualize critical thinking skills optimally. Thus, such research has strong relevance to learning in the era of society 5.0 with students as locus control in the accessibility of complex technology. 


\section{RECOMMENDATIONS}

Recommendations for further research are related to the implementation of the IBPBL model in ideal learning situations. The COVID-19 pandemic provides several limitations in the learning process, mainly related to educational interactions between teachers and students. Considering that this research activity was carried out during the COVID-19 pandemic, it has several limitations in its implementation in the field.

\section{REFERENCES}

Altıok, S., Başer, Z., \& Yükseltürk, E. (2019). Enhancing metacognitive awareness of undergraduates through using an eeducational video environment. Computers and Education, 139. https://doi.org/10.1016/j.compedu.2019. 05.010

Aquino, K. C., \& BuShell, S. (2020). Device Usage and Accessible Technology Needs for Post-Traditional Students in the eLearning Environment. Journal of Continuing Higher Education, 68(2). https://doi.org/10.1080/07377363.2020.1 759313

Bahri, A., Idris, I. S., Muis, H., Arifuddin, M., \& Fikri, M. J. N. (2020). Blended Learning Integrated with Innovative Learning Strategy to Improve SelfRegulated Learning. International Journal of Instruction, 14(1). https://doi.org/10.29333/IJI.2021.14147 A

Baszuk, P. A., \& Heath, M. L. (2020). Using Kahoot! to increase exam scores and engagement. Journal of Education for Business, 95(8). https://doi.org/10.1080/08832323.2019.1 707752

Bloom, L. A., \& Doss, K. (2020). Using Technology to Foster Creative and Critical Thinking in the Classroom. In Research Anthology on Developing Critical Thinking Skills in Students. https://doi.org/10.4018/978-1-79983022-1.ch028

Carolina Torres Escobar, A. (2021). Enhancing Self-Regulation and
Metacognition in Online Learning. In Education in Childhood [Working Title]. https://doi.org/10.5772/intechopen.99104

Chang, C.-Y., Kao, C.-H., \& Hwang, G.-J. (2020). Facilitating Students' Critical Thinking and Decision Making Performances. Educational Technology \& Society, 23(2).

Dexter, S., Francisco, A., \& Luke Luna, C. (2021). Five leading-edge K-12 districts' decision-making processes for EdTech innovations. Journal of Educational Administration, $59(3)$. https://doi.org/10.1108/JEA-10-20200222

Dinata, P. A. C., Suparwoto, S., \& Sari, D. K. (2020). Problem-Based Online Learning Assissted by Whatsapp to Facilitate The Scientific Learning of 2013 Curriculum. Berkala Ilmiah Pendidikan Fisika, 8(1). https://doi.org/10.20527/bipf.v8i1.7647

Dolan, A. M., Waldron, F., Pike, S., \& Greenwood, R. (2014). Student teachers' reflections on prior experiences of learning geography. International Research in Geographical and Environmental Education, 23(4), 314 330.

https://doi.org/10.1080/10382046.2014.9 46324

Duma, L., \& Monda, E. (2013). Impact of ICT based education on the information society. Journal of Futures Studies, 18(1).

Effendi, H., \& Hendriyani, Y. (2020). The Conceptual and Hypothetical Model of Interactive Blended Problem Based Learning. JPI (Jurnal Pendidikan Indonesia), $\quad 8(2)$. https://doi.org/10.23887/jpiundiksha.v8i2.24162

Ennis, R. H. (1996). Critical Thinking Dispositions: Their Nature and Assessability. Informal Logic, 18(2). https://doi.org/10.22329/il.v18i2.2378

Fitri Rahmawati, B., Zidni, \& Suhupawati. (2020). Learning by Google Classroom in Students' Perception. Journal of Physics: Conference Series, 1539(1). https://doi.org/10.1088/17426596/1539/1/012048 
Fu, B., Damer, N., Kirchbuchner, F., \& Kuijper, A. (2020). Sensing technology for human activity recognition: A comprehensive survey. IEEE Access, 8. https://doi.org/10.1109/ACCESS.2020.2 991891

Gladden, M. E. (2019). Who will be the members of Society 5.0? Towards an anthropology of technologically posthumanized future societies. Social Sciences, $8(5)$. https://doi.org/10.3390/socsci8050148

Guo, Q., Wang, X., Wu, Y., Yu, Z., Liang, D., $\mathrm{Hu}, \quad \mathrm{X} ., \quad \&$ Luo, P. (2020). Online knowledge distillation via collaborative learning. Proceedings of the IEEE Computer Society Conference on Computer Vision and Pattern Recognition.

https://doi.org/10.1109/CVPR42600.202 0.01103

Harshman, J. (2016). Critical Global Competence and the $\mathrm{C} 3$ in Social Studies Education. The Social Studies, 107(5). https://doi.org/10.1080/00377996.2016.1 190915

Hintermann, C., Bergmeister, F. M., \& Kessel, V. A. (2020). Critical Geographic Media Literacy in Geography Education: Findings from the MiDENTITY Project in Austria. Journal of Geography, 119(4). https://doi.org/10.1080/00221341.2020.1 761430

Jaedun, A. (2011). METODOLOGI PENELITIAN EKSPERIMEN. In Metodologi Penelitian Eksperimen.

Jahanian, R., \& Rajabi, H. (2016). The comparison of critical thinking skills for juniors' girl students in smart and ordinary schools. International Journal of Educational and Psychological Researches, 2(2). https://doi.org/10.4103/23952296.178862

Larsen, T. B., \& Harrington, J. A. (2018). Developing a Learning Progression for Place. In Journal of Geography (Vol. 117, Issue 3). https://doi.org/10.1080/00221341.2017.1 337212

Lee, J. (2020). Designing an inquiry-based field work project for students using mobile technology and its effects on students' experience. Review of International Geographical Education Online, 10(Speciallssue1). https://doi.org/10.33403/rigeo.637666

Lee, J., Catling, S., Kidman, G., Bednarz, R., Krause, U., Martija, A. A., Ohnishi, K., Wilmot, D., \& Zecha, S. (2021). A multinational study of authors' perceptions of and practical approaches to writing geography textbooks. International Research in Geographical and Environmental Education, 30(1). https://doi.org/10.1080/10382046.2020.1 743931

Legido-Quigley, H., Asgari, N., Teo, Y. Y., Leung, G. M., Oshitani, H., Fukuda, K., Cook, A. R., Hsu, L. Y., Shibuya, K., \& Heymann, D. (2020). Are highperforming health systems resilient against the COVID-19 epidemic? In The Lancet (Vol. 395, Issue 10227). https://doi.org/10.1016/S01406736(20)30551-1

Mehren, R., Rempfler, A., Buchholz, J., Hartig, J., \& Ulrich-Riedhammer, E. M. (2018). System competence modelling: Theoretical foundation and empirical validation of a model involving natural, social and human-environment systems. Journal of Research in Science Teaching, 55(5). https://doi.org/10.1002/tea.21436

Musthofa, P. R., \& Sujadi, I. (2020). The students' perception of the teacher's apperception and its influence on students' initial knowledge. Journal of Physics: Conference Series, 1465(1). https://doi.org/10.1088/17426596/1465/1/012063

Nargundkar, S., Samaddar, S., \& Mukhopadhyay, S. (2014). A guided problem-based learning (PBL) approach: Impact on critical thinking. Decision Sciences Journal of Innovative Education, 12(2). https://doi.org/10.1111/dsji.12030

Nugraha, M. S., Liow, R., \& Evly, F. (2021). (2021). The Identification of Online Strategy Learning Results While Students Learn from Home During the Disruption 
of the COVID-19 Pandemic in Indonesia. Journal of Contemporary Issues in Business and Government, 27(02). https://doi.org/10.47750/cibg.2021.27.02 .205

Oderinu, O. H., Adegbulugbe, I. C., Orenuga, O. O., \& Butali, A. (2020). Comparison of students' perception of problem-based learning and traditional teaching method in a Nigerian dental school. European Journal of Dental Education, 24(2). https://doi.org/10.1111/eje.12486

Oktavianto, D. A., Sumarmi, \& Handoyo, B. (2017). the Effect of Project-Based Learning Assisted Google Earth To Spatial Thinking Skills. Jurnal Teknodik, 21(1), 1-15. https://jurnalteknodik.kemdikbud.go.id/i ndex.php/jurnalteknodik/article/view/227

Pereira, A. G., Lima, T. M., \& Charrua-Santos, F. (2020). (2020). Industry 4.0 and Society 5.0: Opportunities and Threats. International Journal of Recent Technology and Engineering, 8(5). https://doi.org/10.35940/ijrte.d8764.0185 20

Prasetya, S. P. (2018). Effect of Learning Media Variation to Increase Interest and Learning Outcomes of Geography. https://doi.org/10.2991/icei-18.2018.122

Putra, A. ., Sumarmi, S., Sahrina, A., Fajrilia, A., Islam, M. N., \& Yembuu, B. (2021). Effect of Mobile-Augmented Reality (MAR) in Digital Encyclopedia on The Complex Problem Solving and Attitudes of Undergraduate Student. International Journal of Emerging Technologies in Learning (IJET), 16(07). https://doi.org/10.3991/ijet.v16i07.21223

Rahmatia Rahmatia, Ahmad Yani, N. N. (2018). IMPLEMENTATION STRATEGY OF GEOGRAPHY LEARNING PROCESS BASED ON CURRICULUM 2013 IN BACKWARD REGIONS (Case Study in Lebak Regency, Banten). SOSIO-DIDAKTIKA: Social Science Education Journal, 1(1). https://doi.org/10.15408/sd.v1i1.7447

Ratti, B. (2018). Geographic Knowledge. Paradigm of Society 5.0. Copyright $(\mathrm{C}$ Nuova Cultura Italian Association of
Geography Teachers Journal of Research and Didactics in Geography (JREADING, 1(7).

Rosa, A. T. R., \& Mujiarto. (2020). Teacher development potential (Creativity and innovation) education management in engineering training, coaching and writing works through scientific knowledge intensive knowledge based on web research in the industrial revolution and society. International Journal of Higher Education, 9(4). https://doi.org/10.5430/ijhe.v9n4p161

Sajidan, S., Saputro, S., Perdana, R., Atmojo, I. R. W., \& Nugraha, D. A. (2020). Development of Science Learning Model towards Society 5.0: A Conceptual Model. Journal of Physics: Conference Series, 1511(1). https://doi.org/10.1088/17426596/1511/1/012124

Saptorini, P., Abdul, M., \& Binfas, M. (2021). the Evaluation of Senior High School Geography Curriculum Using Countenance'S Model and a. 21(April), 93-101.

Sari, R. M., Sumarmi, Astina, I. K., Utomo, D. H., \& Ridhwan. (2021). Increasing Students Critical Thinking Skills and Learning Motivation Using Inquiry Mind Map. International Journal of Emerging Technologies in Learning, 16(3). https://doi.org/10.3991/ijet.v16i03.16515

Shiroishi, Y., Uchiyama, K., \& Suzuki, N. (2018). Society 5.0: For Human Security and Well-Being. Computer, 51(7). https://doi.org/10.1109/MC.2018.301104 1

Short, M. N., \& Keller-Bell, Y. (2020). Essential Skills for the 21st Century Workforce. In Research Anthology on Developing Critical Thinking Skills in Students. https://doi.org/10.4018/978-17998-3022-1.ch006

Sugiyanto, S., Maryani, E., \& Ruhimat, M. (2021). Development of social teaching materials based on geography literacy for increasing, critical, and creative thinking skills. IOP Conference Series: Earth and Environmental Science, 683(1). https://doi.org/10.1088/1755- 
$1315 / 683 / 1 / 012042$

Sugiyono, P. D. (2016). metode penelitian kuantitatif, kualitatif,dan R\&D. Alfabeta, Cv.

Sujanem, R., Nyoman Putu Suwindra, I., \& Suswandi, I. (2020). The Effectiveness of Problem-Based Interactive Physics EModule on High School Students' Critical Thinking. Journal of Physics: Conference Series, 1503(1). https://doi.org/10.1088/17426596/1503/1/012025

Suzuki, K., Morita, S., Endo, K., Yamamoto, T., Fujii, S., Ohya, J., Masamune, K., \& Sakai, S. (2021). Learning effectiveness of using augmented reality technology in central venous access procedure: an experiment using phantom and headmounted display. International Journal of Computer Assisted Radiology and Surgery, 16(6). https://doi.org/10.1007/s11548-02102365-6

Tsai, M. H., \& Tang, Y. C. (2017). Learning attitudes and problem-solving attitudes for blended problem-based learning. Library Hi Tech, 35(4). https://doi.org/10.1108/LHT-06-20170102

Tsang, K. K., To, H. K., \& Chan, R. K. H. (2020). Nurturing the global competence of high school students in shenzhen: The impact of school-based global learning education, knowledge, and family income. KEDI Journal of Educational Policy, $17(2)$. https://doi.org/10.22804/kjep.2020.17.2. 003

Ural, E., \& Dadli, G. (2020). The Effect of Problem-based Learning on 7th-grade Students' Environmental Knowledge, Attitudes, and Reflective Thinking Skills in Environmental Education. Journal of Education in Science, Environment and Health. https://doi.org/10.21891/jeseh.705145

Wang, X., Men, W., Gao, J., Caramazza, A., \& Bi, Y. (2020). Two Forms of Knowledge Representations in the Human Brain. Neuron, 107(2). https://doi.org/10.1016/j.neuron.2020.04.
010

Wong, I. L. (2013). Developing independent learning skills for postgraduate students through blended learning environment. Journal of Cases on Information Technology, 15(1). https://doi.org/10.4018/jcit.2013010103

Yuan, K., Aftoni, A., \& Çobanoğlu, Ö. (2020). The Effect of Problem-Based Learning Model and Blended Learning Model to Metacognitive Awareness as a Reflection Towards a New Normal Era. Jurnal Pendidikan Teknologi Dan Kejuruan, 26(2). https://doi.org/10.21831/jptk.v26i2.3278 3

Zamroni, E., Muslihati, Lasan, B. B., \& Hidayah, N. (2020). Blended Learning based on Problem Based Learning to Improve Critical Thinking Ability of Prospective Counselors. Journal of Physics: Conference Series, 1539(1). https://doi.org/10.1088/17426596/1539/1/012039 